\title{
VARIATIONS AND MANAGEMENT OF BILE DUCT INJURY IN POST-CHOLECYSTECTOMY
}

\author{
Muhammad Sayuti ${ }^{1}$ \\ ${ }^{1}$ Bagian Ilmu Bedah, Fakultas Kedokteran, Universitas Malikussaleh \\ Corresponding Author : say_md@yahoo.com
}

\begin{abstract}
Abstrak
Bile Duct Injury (BDI) dapat terjadi pada kasus kolesistektomi. Insiden BDI pada kolesistektomi terbuka berkisar $0,1-0,2 \%$ dan $0,4-0,5 \%$ pada kolesistektomi laparoskopi. Tujuan dari penelitian ini adalah untuk menentukan variasi yang paling sering dari BDI dan manajemennya. Pasien cedera duktus biliaris yang dirawat di rumah sakit umum Pusat Dr. Kariadi dan Rumah Sakit Telogorejo Semarang dari Juli 2014 hingga Desember 2015 dianalisis secara retrospektif. Variasi cedera diklasifikasikan menggunakan klasifikasi Strasberg. Jumlah total pasien adalah empat belas, enam (42,9\%) laki-laki dan delapan $(57,1 \%)$ perempuan. Usia mereka berkisar antara 28 tahun hingga 70 tahun dan usia rata-rata adalah 49 tahun. Mereka dirujuk oleh rekan-rekan dari kota-kota di sekitar Semarang. Sembilan pasien $(64,2 \%)$ setelah laparoskopi, dan lima pasien $(35,8 \%)$ setelah kolesistektomi terbuka. Sebelas pasien $(78,57 \%)$ mengeluh sakit perut dan sakit kuning. Tiga pasien $(21,43 \%)$ hanya mengeluh sakit kuning dan satu pasien $(7,14 \%)$ dengan kolangitis. Untuk diagnosis, kami melakukan USG (5 pasien), MRCP ( 9 pasien), ERCP (8 pasien) dan PTBD (6 pasien). Jenis BDI yang paling sering menurut klasifikasi Strasberg adalah Strasberg E-2 sebanyak lima kasus $(35,71 \%)$ dan tipe E-1 adalah tiga kasus $(21,43 \%)$. Tipe D dua kasus (14, $29 \%$ ), tipe E-3 dua kasus $(14,29 \%)$, tipe A satu kasus $(7,14 \%)$ dan E-4 satu kasus $(7,14 \%)$. Kami melakukan hepaticojejunostomy Roux en Y pada delapan pasien $(57,14 \%)$, tiga pasien $(21,43 \%)$ ekstraksi klip dan lampiran T-tube, satu pasien $(7,14 \%)$ memasang t-tabung saja, satu pasien $(7,14 \%)$ mendapat drainase biloma, dan pada satu pasien kami melakukan PTBD (pasien hilang dari pengamatan karena dia tidak datang untuk dievaluasi). Dalam penelitian ini, BDI yang paling sering ditemukan adalah Strasberg tipe E-2. Sebagian besar kasus BDI dapat direkonstruksi menggunakan hepaticojejunostomi dengan hasil yang baik dan memuaskan.
\end{abstract}

Kata Kunci : bile-duct-injury, bile leak, kolesistektomi 


\title{
VARIATIONS AND MANAGEMENT OF BILE DUCT INJURY IN POST-CHOLECYSTECTOMY
}

\begin{abstract}
Bile Duct Injury (BDI) can occurs in cholecystectomy cases. The incidence of BDI in open cholecystectomy ranged from $0.1-0.2 \%$ and $0.4-0.5 \%$ in laparoscopic cholecystectomy. The aims of this study is to determine the most frequent variations of BDI and its management. Bile duct injury patients admitted to the Dr. Kariadi general hospital centers and Telogorejo Hospital Semarang from July 2014 until December 2015 were a retrospectively analysed. The variations of the injury were classified using the Strasberg's classification. Total numbers of patients was fourteen, six (42.9\%) males and eight (57.1\%) females. Their age ranged from 28 years to 70 years and the average age was 49 years. They were referred by colleagues from cities around Semarang. Nine patients (64.2\%) after laparoscopic, and five patients (35.8\%) after open cholecystectomy. Eleven patients (78.57\%) complained of abdominal pain and jaundice. Three patients $(21.43 \%)$ only complained of jaundice and one patient $(7.14 \%)$ with cholangitis. For diagnosis, we did an USG (5 patients), MRCP (9 patients), ERCP (8 patients) and PTBD (6 patients). The most frequent type of BDI according to the Strasberg classification was Strasberg E-2 as many as five cases (35.71\%) and thentype E-1 was three cases $(21.43 \%)$. Type D two cases $(14,29 \%)$, type E-3 two cases $(14,29 \%)$, type A one case (7.14\%)and E-4 one case $(7.14 \%)$. We performed hepaticojejunostomy Roux en Y in eight patients $(57.14 \%)$, three patients $(21.43 \%)$ clip extraction and a T-tube attachment, one patient (7.14\%) attachment a T-tube only,one patient $(7,14 \%)$ got biloma drainage, and in one patientwe performed PTBD (patient was lost from observation because he did not cometo be evaluated). In this study, the most frequent found of BDI is Strasberg type E-2. Most cases of BDI can be reconstructed using hepaticojejunostomi with good and satisfactory results.
\end{abstract}

Keywords: bile duct injury, bile leak, cholecystectomy 


\section{PENDAHULUAN}

Kolelitiasis merupakan salah satu kasus bedah digestif yang paling sering dijumpai dalam praktek klinik. Manajemen bedah untuk kolelitiasis simptomatik adalah kolesistektomi baik secara open maupun secara laparoskopi. Sama halnya dengan teknik bedah secara umum, teknik bedah kolesistektomi juga dapat menyebabkan beberapa risiko dan komplikasi, salah satu risiko yang bisa terjadi adalah bile duct injury (BDI). Insidensi BDI bervariasi antara $0 \%$ sampai $1 \%$, pada open kolesistektomi berkisar antara 0,1-0,2 \%, sedangkan pada laparoskopi kolesistektomi 0,4-0,6\%. Sebagian besar (77\%-89\%) cidera diketahui setelah operasi,yang memberikan gejala klinis berupa nyeri abdomen, bile leak, jaundice, maupun kolangitis. ${ }^{1}$

Klasifikasikan BDI ada beberapa macam, ini didasarkan pada mekanisme, tipe dari cidera dan lokasi cidera.1Saat ini ada berbagai macam klasifikasi yang diajukan, salah satu yang sering dipakai adalah klasifikasi Strasberg. Modalitas pengobatan untuk BDI bisa secara pembedahan, endoskopi maupun secara radiologi intervensi, pemilihan jenis tindakan didasarkan pada lokasi dan beratnya cidera. ${ }^{1}$

Saat ini belum ada data di Indonesia berapa insidensi dan tipe BDI yang mana yang paling sering terjadi post kolesistektomi.Maka melalui studi ini diharapkan didapatkan data jumlah dan tipe BDI yang paling sering terjadi serta manajemennya yang tangani di bagian bedah digestif Fakultas Kedokteran UNDIP Semarang.

\section{TINJUAN PUSTAKA}

Bile duct injury (BDI) banyak terjadi dalam praktek klinis. Mekanisme terjadinya cedera, upaya perbaikan sebelumnya, risiko bedah dan status kondisi umum penderita berpengaruh penting dalam pengambilan keputusan untuk menentukan tindakan diagnostik maupun terapetik. Pendekatan multi disiplin termasuk penyakit dalam, bedah, endoskopi dan radiologi intervensi dibutuhkan untuk mengelola penyakit yang kompleks ini. ${ }^{2}$

BDI dapat terjadi pada pembedahan kolesistektomi, pankreas dan gaster, dimana 80\%$85 \%$ diantaranya ditemukan pada laparoskopi kolesistektomi. ${ }^{2}$ Walaupun secara statistik tidak signifikan, BDI pada laparoskopi kolesistektomi dilaporkan dua kali lebih sering ketimbang pada open kolesistektomi (0,3\% open vs $0,6 \%$ laparoskopi). ${ }^{2}$ 


\section{Presentasi klinis}

Gejala klinis yang umum adalah jaundice, demam, menggigil, nyeri epigastrium dan pruritus. Presentasi klinis tergantung jenis cidera dan di bagi menjadi dua kelompok.Pada kelompok dengan kebocoran empedu pada periode awal post operasi, karena BDI. Jika masih ada drain, akan kelihatan keluar bile dari drain, sedangkan jika tidak ada drain, akan terjadi kumpulan bile di regio sub hepatik yang kemudian bisa berkembang menjadi biloma, peritonitis bile atau berkembang menjadi abses. Pada pasien seperti ini dapat timbul demam, nyeri perut dan tanda-tanda sepsis bisa terjadi. Jaundice pada kelompok ini tidak terjadi karena tidak ada kolestasis. Pada kelompok kedua yaitu striktur bilier, ikterus yang disebabkan oleh kolestasis merupakan gejala klinis yang paling umum. 5,6

\section{Diagnosis bile duct injury}

Pemeriksaan laboratorium dan imaging digunakan untuk mendiagnosis BDI. Pada pemeriksaan laboratorium, indikator kolestasis dan fungsi liver seperti bilirubin, alkali fosfatase (FA), gamma-glutamil transpeptidase (GGT), alanine transaminase (ALT), dan aspartate transaminase (AST), yang paling sering digunakan. Pada pasien dengan kolestasis stenosis bilier parameter yang meningkat adalah bilirubin serum, FA, GGT, dan 5 nukleotidase dan leusin aminopeptidase (LAP) (kurang tersedia di laboratorium), dan nilainilai transaminase biasanya tetap normal (hati tidak rusak). Level transaminase meningkat mengindikasikan kerusakan parenkim hati dan perkembangan sirosis bilier sekunder, dan hipoalbuminemia, waktu pro thrombin yang berkepanjangan terjadi karena kerusakan fungsi sintetis hati. ${ }^{5,6}$

Dalam mendiagnosis BDI dapat menggunakan pencitraan ultra sonografi (USG), abdominal computed tomography scan (CT Scan abdomen), perkutaneus kolangiografi, endoskopi kolangiografi, dan magnetic resonance imaging (MRI) abdomen. USG abdomen memungkinkan visualisasi duktus bilier intra dan ekstra hepatic dengan pengukuran lebar dan melihat biloma dalam rongga peritoneum pada kasus bile leak.Penilaian biliary tree yang lebih akurat dapat di buat dengan kolangiografi.Kolangiografi perkutan (percutaneous transhepatic cholangiography/ PTC) berguna untuk mengevaluasi saluran empedu proksimal dari cidera.Kolangigrafi endoskopi (Endoskopi retrograde cholangiopancreaticography/ ERCP) memiliki peran yang sangat penting dalam pencitraan BDI.Selama ERCP dapat dilakukan pemasangan stent ke dalam duktus biliaris yang cidera.Keuntungan dari MRI cholangiografi (Magnetic resonance cholangiopancreaticography/MRCP) adalah memiliki 
akurasi tinggi untuk biliary tree dan bersifat non invasif. Penilaian ini terutama digunakan untuk menilai saluran empedu sebelum tindakan rekonstruksi. 5,6

\begin{tabular}{|c|c|c|}
\hline Modality & Advantages & Disadvantages \\
\hline $\begin{array}{l}\text { Hepalobsiony } \\
\text { Scan }\end{array}$ & - Senstive for leak deloction & 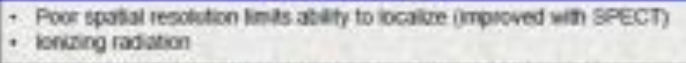 \\
\hline $\begin{array}{l}\text { Utrowand and } \\
\text { CT }\end{array}$ & 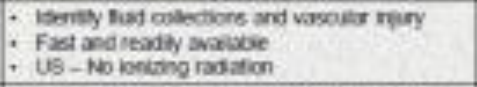 & 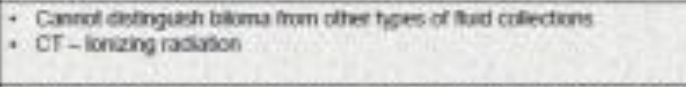 \\
\hline MEISKACP & 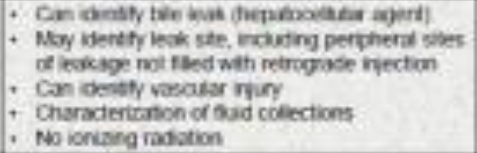 & 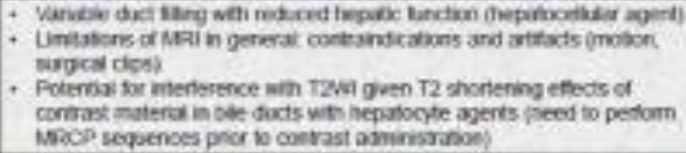 \\
\hline Farp: & 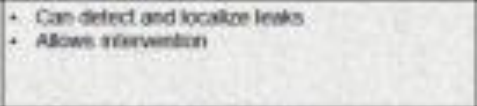 & 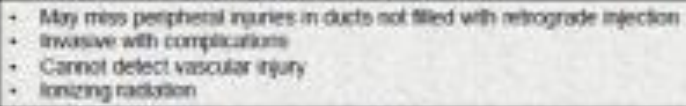 \\
\hline PTC & 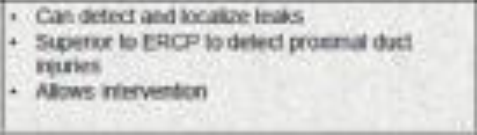 & 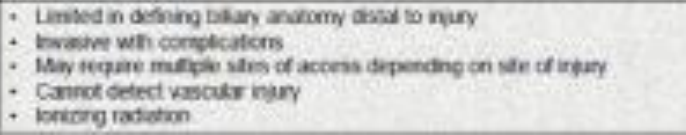 \\
\hline
\end{tabular}

\section{Gambar 1. Modality for diagnosis BDI}

\section{Klasifikasi bile duct injury}

Ada berbagai macam klasifikasi bile duct injury, salah satu yang paling sering di pakai adalah klasifikasih dari Strasberg. ${ }^{7,8}$

$\begin{aligned} & \text { Cystic duct leak } \\ & \text { Kebocoran empedu dari saluran } \\ & \text { empedu minor yang masih } \\ & \text { berhubungan dengan duktus komunis; } \\ & \text { termasuk ujung sisa duktus sistikus atau } \\ & \text { duktus asesoris (Luschka). }\end{aligned} \mid \begin{aligned} & \text { Right aberrant duct ligation } \\ & \text { Oklusi satu bagian saluran empedu. } \\ & \text { Sering terjadi pada duktus hepatikus } \\ & \text { kanan aberans yang diduga duktus } \\ & \text { sistikus. }\end{aligned}$




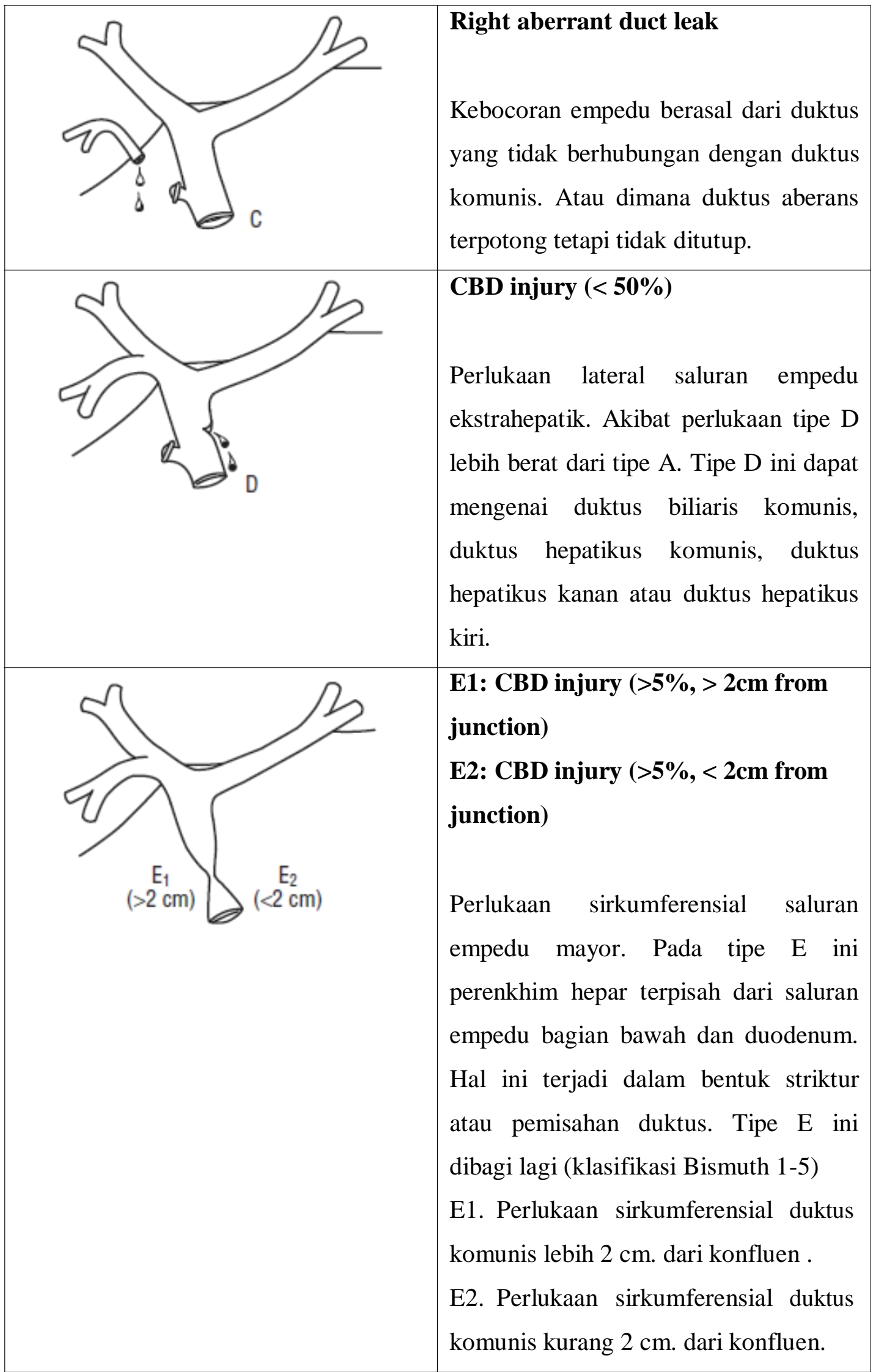




CBD injury (high)
$\begin{aligned} & \text { Perlukaan sirkumferensial duktus } \\ & \text { komunis pada konfluen. Duktus } \\ & \text { hepatikus kanan dan kiri masih } \\ & \text { berhubungan. }\end{aligned}$
CBD injury (dividing left \& right
Pepatic ducts)
atau kiri.
CBD \& right aberrant injury

Gambar 2. Klasifikasi Strasberg-Bismuth

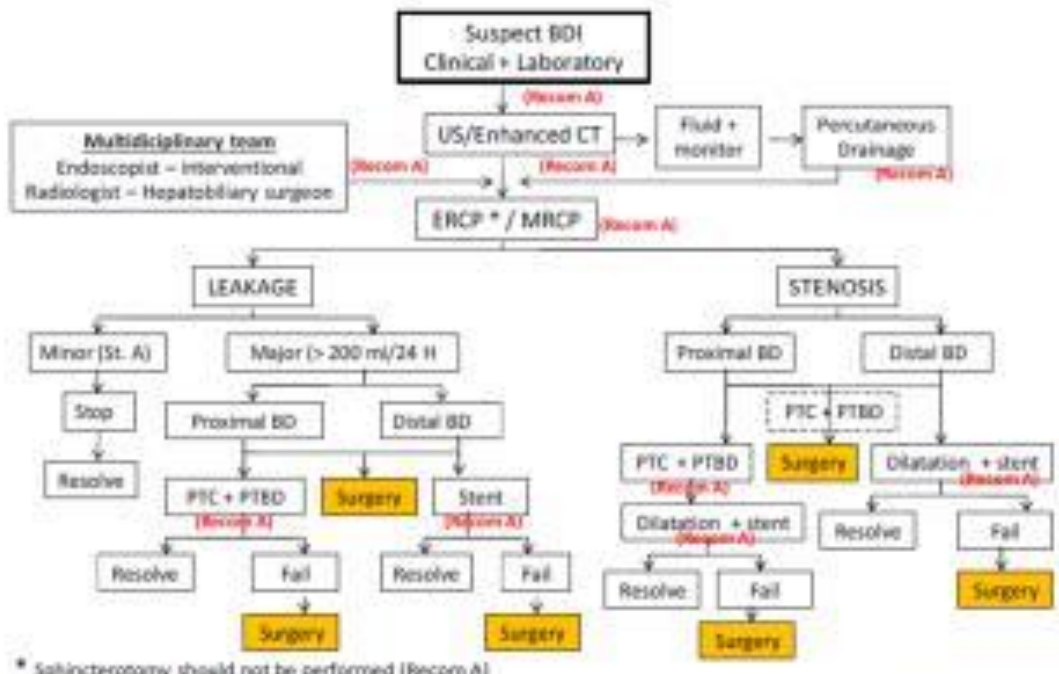

BDA : bite dict injury, US : ulrasound, CT : computed tomograply, ERCP : endoscopic retrograde chotraziopancreanoaraphy

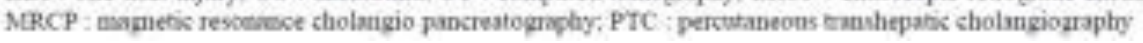

Gambar 3. ALGORITHM OF BILE DUCT INJURY (Recommendation EAES (2012) 9 


\section{Penanganan bile duct injury}

Bile duct injury (BDI) harus diperlakukan sesuai dengan jenis cidera. Klasifikasi Strasberg bermanfaat untuk memutuskan intervensi yang terbaik untuk setiap kasus sesuai dengan mekanisme etiologi cidera.

Tujuan dari manajemen BDI adalah menghidupkan kembali aliran masuk ke traktus gastrointestinal proksimal, mencegah kolangitis, pembentukan sludge atau batu, pembentukan striktur lagi, dan kerusakan hepar yang progresif.

- Strasberg A:

Menjaga kontinyuitas dari duktus biliaris yang tersisa, mudah dengan intervensi endoskopi.Dapat dilakukan ERCP \pm sphincterotomy \pm stent.Tujuannya untuk mengurangi tekanan intraduktal distal ke saluran empedu yang bocor.Jika tidak ada endoskopi, dapat menggunakan T-tube.Jika itupun tidak ada, dapat di pasang drain sub hepatal untuk mengontrol kebocoran empedu dan kemudian dirujuk ke center yang lebih lengkap. ${ }^{7}$

- Strasberg B:

Oklusi duktus biliaris segmental adalah merupakan penyebab dari tipe ini.Jika nyerinya ringan, peningkatan test fungsi liver tanpa gangguan klinis dapat dilakukan dengan manajemen konservatif.Adanya kolangitis yang sedang atau berat diperlukan drainase dari segmen yang oklusi.Drainase perkutaneus atau reseksi bedah dapat dilakukan jika kolangitis tidak membaik dengan pengobatan.Shunting biliodigestif (anastomosis hepatiko yeyenostomi dengan memasang NGT 5F sebagai stent bilier) dari duktus bilier segmental dapat dilakukan walaupun kadang agak sulit.Prognosis jangka panjang jelek dan probabilitas tinggi terjadinya pengumpulan bile atau kolangitis. ${ }^{7}$

\section{- Strasberg C:}

Tidak adanya kontinyuitas dengan system duktus bilier yang tersisa membuat tidak mungkin dilakukan secara endoskopi. Koleksi bile sub hepatic sering terjadi post operasi, ini harus di drainase untuk mencegah berkembang menjadi peritonitis atau syok sepsis. Biasanya dapat tertutup secara spontan, jika tidak menutup dapat dilakukan manajemen seperti untuk cidera tipe Strasberg B yaitu biliodigestif shunting (dengan prognosis jangka panjang juga jelek), drainase perkutaneus dan hepatektomi. ${ }^{7}$ 
- Strasberg D:

Jika cidera kecil tanpa devaskularisasi, dapat di jahit dengan monofilament 5.0 absorbable.Pada kasus yang jarang terjadi, bisa di pasang drainase eksternal kemudian di lakukan endoskopi, wajib dilakukan spinterotomi kemudian dipasang stent. Pada keadaan dengan devaskularisasi (iskemia yang signifikan, kerusakan karena kauter di tempat cidera), walaupun sudah dijahit dengan monofilamen 5.0 absorbable, dapat terjadi bile leak pada minggu pertama post operasi dan koleksi bile akan berulang. Manajemen kasus seperti ini membutuhkan pendekatan multidisiplin, dengan pendekatan endoskopi dan drainase dipandu radiologi sebagai pilihan pertama. Operasi anastomosis hepatiko yeyenostomi adalah pilihan terakhir jika ditemukan adanya jaringan duktus bilier yang hilang dan berpindah menjadi cidera tipe D atau E. 7

- Cidera tipe Strasberg E:

Devaskularisasi dan hilangnya jaringan duktus biliaris diwajibkan untuk dilakukan anastomosis hepatiko yeyenostomi berkualitas tinggi, yang menjamin perfusi duktus biliaris yang baik dan anastomosis yang tidak tegang (untuk. Sebaliknya jika dilakukan anastomosis koledoko-koledoko atau anastomosis hepatiko-duedenum dimana duktus bilier yang devaskularisasi dipakai untuk rekonstruksi dan duodenum yang cenderung bergerak ke bawah akan meningkatkan ketegangan anastomosis (walaupun sudah dilakukan kocher dengan baik).

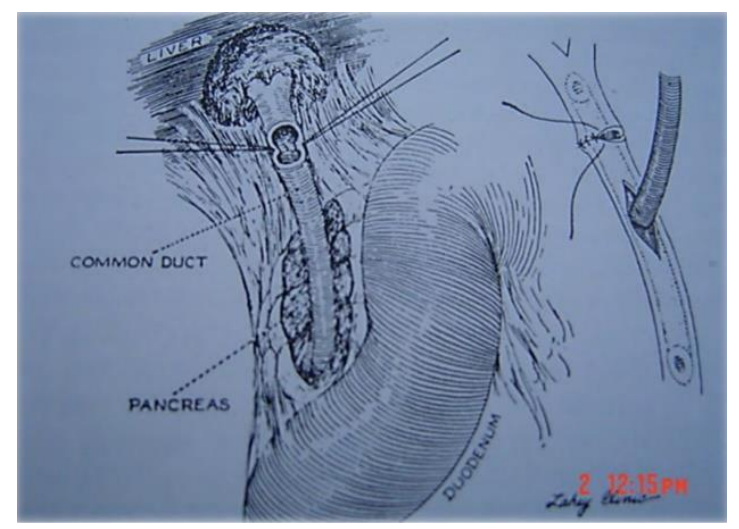

Gambar 4. Anastomosis koledoko-koledoko 


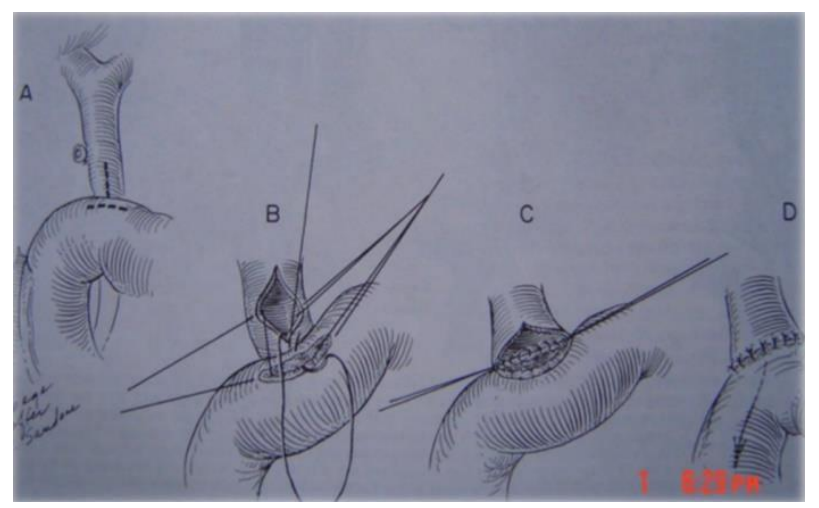

Gambar 5. Anastomosis koledoko-duedenum

Hasil pasca operasi terbaik diperoleh ketika konfluen hepatic dipertahankan, yang memungkinkan berkualitas tinggi, lebar, dan vaskularisasi yang baik untuk anastomosis hepatiko yeyenal.

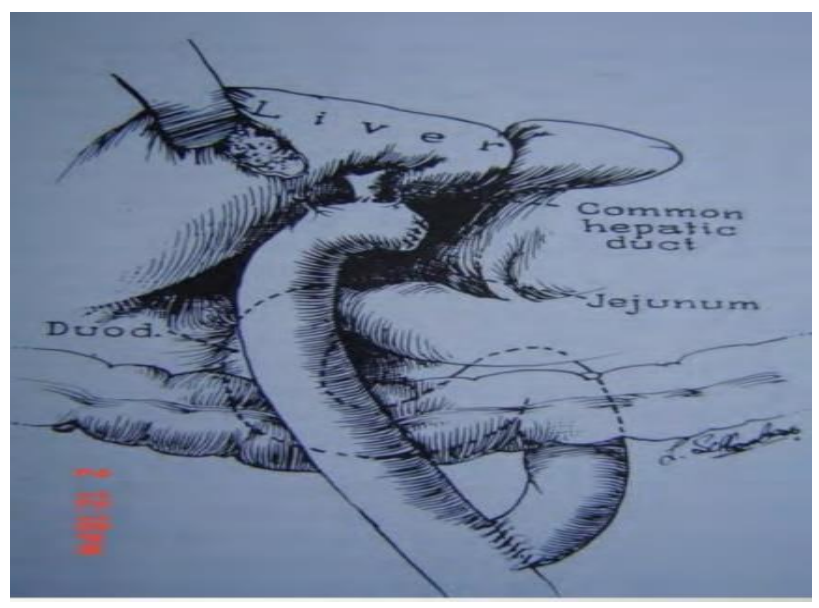

Gambar 6. Hepatiko yeyenostomi Roux en Y

Parsial reseksi hepar segmen IV dan V memungkinkan identifikasi yang baik duktus bilier dan dapat menempatkan loop yeyenum secara tepat. Pada situasi yang tidak memadai dilakukan suatu hepatiko yeyenostomi, loop yeyenum harus di jahit ke parenkim hepar termasuk anastomosis duktus biliaris, sama dengan suatu Kazai portoenterostomi. Sebagian besar kasus seperti ini akan memerlukan transplantasi hepar jika operasi portoenterostomi tidak memberikan hasil yang baik. ${ }^{7}$ 

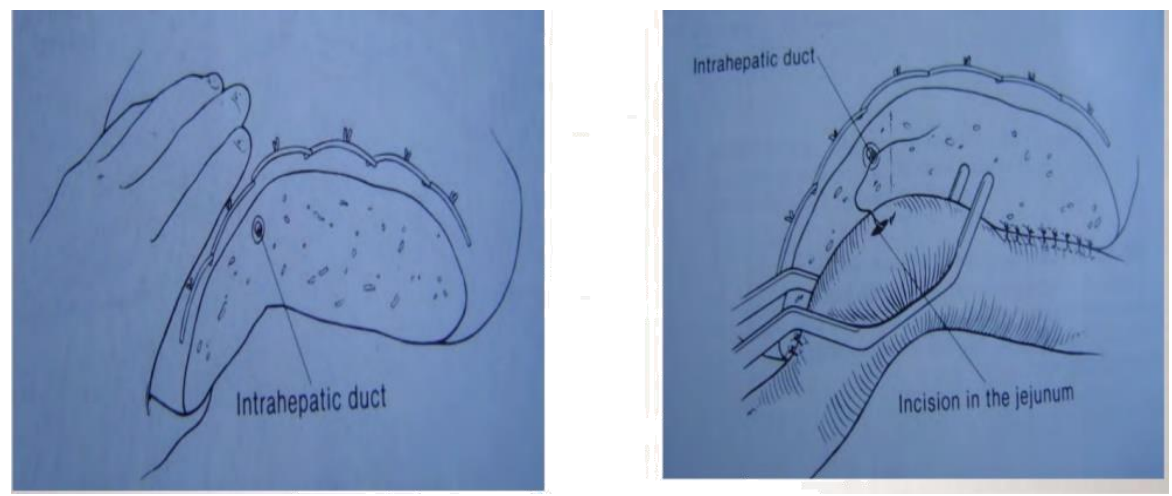

Gambar 7. Intrahepatik kolangio-yeyenostomi (Longmire)
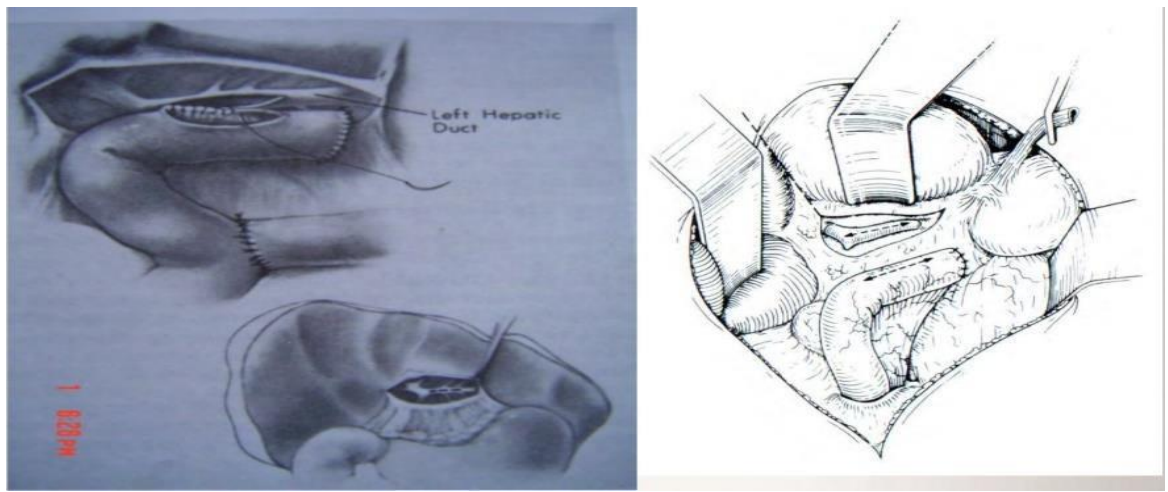

Gambar 8. Left hepatic duct anastomosis (Segment III/ Hepp-Couinaud)

\section{METODE PENELITIAN}

Tiap kasus yang dirujuk ke bagian UGD Rumah Sakit umum pusat (RSUP) DR Kariadi dan Rumah Sakit (RS) Tlogorejo dari Juli 2014 s/d Desember 2015 dengan diagnosis post laparoskopi kolesistektomi atau open kolesistektomi dan data dari kamar operasi dengan keterangan tindakan rekonstruksi bilier dari rentang waktu tersebut dikumpulkan datanya kemudian di ambil data lengkap dari bagian rekam medik,dilakukan analisa dari rekam medik berdasarkan hasil modalitas pemeriksaan penunjang dan penemuan selama operasi dan jenis rekonstruksi yang dilakukan.Pembagian tipe bile duct injury(BDI) diklasifikasikan menurut klasifikasi Strasberg.

\section{HASIL PENELITIAN}

Total jumlah pasien adalah empat belas orang, enam (42,9\%) laki-laki dan delapan $(57,1 \%)$ perempuan. Rentang umur antara 28 tahun sampai dengan 70 tahun dengan umur rata-rata adalah 49 tahun.Tujuh (50\%) pasien berasal dari rujukan RS tipe B dan tujuh (50\%) pasien berasal dari rujukan RS swasta tipe C. Sembilan (64,2 \%) dari pasien adalah rujukan 
post tindakan laparoskopi kolesistektomi dan lima (35,8 \%) rujukan adalah post tindakan open kolesistektomi. Delapan (57\%) pasien ditangani di RS Tlogorejo dan enam (43\%) pasien ditangani di RSUP DR. Kariadi. Cara BDI yang terjadi seperti dalam table 1.

Tabel 1: Cara bile duct injury

\begin{tabular}{lcc}
\hline \multicolumn{1}{c}{ Prosedur } & Jumlah pasien & Persentase \\
\hline Laparoskopi & 9 & $64,2 \%$ \\
kolesistektomi & & \\
Open kolesistektomi & 5 & $35,8 \%$ \\
\hline
\end{tabular}

Pada sebagian besar pasien keluhan berkembang dalam dua minggu dari post operasi. Sebelas pasien $(78,57 \%)$ mengeluh nyeri abdomen dan jaundice, tiga pasien $(21,43 \%)$ hanya mengeluh jaundice saja, dan satu pasien $(7,14 \%)$ dengan gejala kolangitis (nyeri perut, demam, dan jaundice). Enam kasus (42,86 \%) BDI diketahui kurang dari satu minggu, empat kasus $(28,57 \%)$ BDI diketahui sebelum dua minggu, dan empat kasus $(28,57 \%)$ diketahui setelah lebih dari dua minggu.

Untuk diagnosis dikerjakan USG (5 pasien), MRCP (9 pasien), ERCP ( 8 pasien) dan PTBD (6 pasien).Dari total empat belas pasien, tipe BDI menurut klasifikasi Strasberg yang paling banyak adalah tipe Strasberg E-2 yaitu sebanyak lima kasus (35,71 \%), tipe E-1 sebanyak tiga kasus (21,43 \%), tipe D dan E-3 masing-masing dua kasus (14,29\%) sedangkan tipe A dan E-4 masing-masing satu kasus (7,14 \%) (Tabel 2). Pada sembilan kasus post laparoskopi kolesistektomi, didapatkan BDI tipe E-2 tiga kasus (33,34 \%), tipe E-1 dua kasus $(22,22 \%)$, tipe A, D, E-1 dan E-4 masing-masing satu kasus (11,11\%) (Tabel 3). Sedangkan pada lima kasus post open kolesistektomi, tipe BDI E-2 didapatkan dua kasus (40 \%), tipe D, E-1 dan E-3 masing-masing satu kasus (20\%) (Tabel 4). 
Tabel 2: BDI menurut klasifikasi Strasberg

\begin{tabular}{ccc}
\hline Tipe klasifikasi Strasberg & Jumlah & Persentase \\
\hline Tipe A & 1 & $7,14 \%$ \\
Tipe B & - & - \\
Tipe C & - & - \\
Tipe D & 2 & $14,29 \%$ \\
Tipe E-1 & 3 & $21,43 \%$ \\
Tipe E-2 & 5 & $35,71 \%$ \\
Tipe E-3 & 2 & $14,29 \%$ \\
Tipe E-4 & 1 & $7,14 \%$ \\
Tipe E-5 & - & - \\
\hline Total & 14 & $100 \%$ \\
\hline
\end{tabular}

Tabel 3: BDI pada kasus post laparoskopi kolesistektomi

\begin{tabular}{ccc}
\hline Tipe klasifikasi Strasberg & Jumlah & Persentase \\
\hline Tipe A & 1 & $11,11 \%$ \\
Tipe B & - & - \\
Tipe C & - & - \\
Tipe D & 1 & $11,11 \%$ \\
Tipe E-1 & 2 & $22,22 \%$ \\
Tipe E-2 & 3 & $33,34 \%$ \\
Tipe E-3 & 1 & $11,11 \%$ \\
Tipe E-4 & 1 & $11,11 \%$ \\
Tipe E-5 & - & - \\
\hline Total & 9 & $100 \%$ \\
\hline
\end{tabular}


Tabel 4: BDI pada kasus post open kolesistektomi

\begin{tabular}{ccc}
\hline Tipe klasifikasi Strasberg & Jumlah & Persentase \\
\hline Tipe A & - & - \\
Tipe B & - & - \\
Tipe C & - & - \\
Tipe D & 1 & $20 \%$ \\
Tipe E-1 & 1 & $20 \%$ \\
Tipe E-2 & 2 & $40 \%$ \\
Tipe E-3 & 1 & $20 \%$ \\
Tipe E-4 & - & - \\
Tipe E-5 & - & - \\
\hline Total & 5 & $100 \%$ \\
\hline
\end{tabular}

Tiga belas pasien $(92,86 \%)$ dilakukan laparotomi eksplorasi bilier, delapan pasien diantaranya $(57,14 \%)$ dikerjakan hepatikoyeyenostomi Roux en Y, tiga pasien $(21,43 \%)$ release klip/ hemmolog dan dilanjutkan pasang T-tube, satu pasien $(7,14 \%)$ di pasang T-tube saja, satu pasien $(7,14 \%)$ drainase biloma, dan satu pasien loss observasi karena setelah pasang PTBD pasien tidak pernah kontrol kembali (table 5).

Tabel 5: Penemuan, prosedur dan hasil

\begin{tabular}{|c|c|c|c|c|c|c|}
\hline No & Klinis & Penemuan & & Strasberg & Prosedur & Hasil \\
\hline 1 & $\begin{array}{l}\text { Nyeri } \\
\text { perut, } \\
\text { Jaundice }\end{array}$ & $\begin{array}{l}\text { CBD terklip, } \\
\text { total CBD }\end{array}$ & oklusi & $\overline{E-1}$ & $\begin{array}{l}\text { ERCP: } \\
\text { Spingterotomi, } \\
\text { Gagal kanulasi } \\
\text { Laparotomi: } \\
\text { Release klip } \\
\text { pasang T-tube }\end{array}$ & Baik \\
\hline 2 & $\begin{array}{l}\text { Nyeri } \\
\text { perut, } \\
\text { Jaundice }\end{array}$ & $\begin{array}{l}\text { Oklusi total } \\
\text { proksimal }\end{array}$ & CBD & E-2 & $\begin{array}{l}\text { ERCP: } \\
\text { Spingterotomi } \\
\text { Gagal kanulasi } \\
\text { PTBD: } \\
\text { Gagal } \\
\text { randezvous }\end{array}$ & Baik \\
\hline
\end{tabular}




\begin{tabular}{|c|c|c|c|c|c|}
\hline & & & & $\begin{array}{l}\text { Laparotomi: } \\
\text { HY Roux en Y }\end{array}$ & \\
\hline 3 & Jaundice & Oklusi total CHD & E-3 & $\begin{array}{l}\text { PTBD: } \\
\text { Gagal } \\
\text { randezvous } \\
\text { Laparotomi: } \\
\text { HY Roux en Y }\end{array}$ & Baik \\
\hline 4 & Jaundice & $\begin{array}{lll}\text { Oklusi total } & \text { CHD } \\
\text { distal } & & \\
\end{array}$ & E-2 & $\begin{array}{l}\text { ERCP: } \\
\text { Spingterotomi } \\
\text { Gagal kanulasi } \\
\text { PTBD: } \\
\text { Gagal } \\
\text { randezvous } \\
\text { Laparotomi: } \\
\text { *HY Roux en Y }\end{array}$ & Baik \\
\hline 5 & $\begin{array}{l}\text { Nyeri, } \\
\text { demam, } \\
\text { jaundice }\end{array}$ & Bile leak CBD & $\bar{D}$ & $\begin{array}{l}\text { Laparotomi } \\
\text { pasang T-tube }\end{array}$ & $\begin{array}{c}\text { Sepsis } \\
\text { Membaik }\end{array}$ \\
\hline 6 & $\begin{array}{l}\text { Nyeri } \\
\text { perut, } \\
\text { Jaundice }\end{array}$ & $\begin{array}{l}\text { Oklusi total mid } \\
\text { CBD, } \\
\text { Transeksi CHD }\end{array}$ & E-1 & $\begin{array}{l}\text { ERCP: } \\
\text { Spingterotomi } \\
\text { Laparotomi: } \\
\text { HY Roux en Y }\end{array}$ & Baik \\
\hline 7 & $\begin{array}{l}\text { Nyeri } \\
\text { perut, } \\
\text { Jaundice }\end{array}$ & $\begin{array}{l}\text { CHD terklip, oklusi } \\
\text { total CHD }\end{array}$ & E-2 & $\begin{array}{l}\text { ERCP: } \\
\text { Spingterotomi } \\
\text { Gagal kanulasi } \\
\text { Laparotomi: HY } \\
\text { Roux en Y }\end{array}$ & Baik \\
\hline 8 & Jaundice & Total blok CHD & E-4 & $\begin{array}{l}\text { ERCP: } \\
\text { Spingterotomi } \\
\text { Gagal kanulasi } \\
\text { PTBD: } \\
\text { Gagal } \\
\text { randezvous }\end{array}$ & Baik \\
\hline
\end{tabular}




\begin{tabular}{|c|c|c|c|c|c|}
\hline & & & & $\begin{array}{l}\text { Laparotomi: } \\
\text { HY Roux en Y }\end{array}$ & \\
\hline 9 & $\begin{array}{l}\text { Nyeri } \\
\text { perut, } \\
\text { Jaundice }\end{array}$ & $\begin{array}{l}\text { CHD terligasi, oklusi } \\
\text { total CHD }\end{array}$ & E-3 & $\begin{array}{l}\text { Laparotomi: } \\
\text { HY Roux en Y }\end{array}$ & Baik \\
\hline 10 & $\begin{array}{l}\text { Nyeri } \\
\text { perut, } \\
\text { Jaundice }\end{array}$ & Bile leak CBD & $\bar{D}$ & $\begin{array}{l}\text { ERCP: } \\
\text { Spingterotomi } \\
\text { Gagal kanulasi } \\
\text { PTBD: } \\
\text { Pasang pigtail } \\
\text { sampai } \\
\text { duedenum }\end{array}$ & $\begin{array}{c}\text { Loss } \\
\text { observasi, } \\
\text { pasien tidak } \\
\text { melanjutkan } \\
\text { tindakan }\end{array}$ \\
\hline 11 & $\begin{array}{l}\text { Nyeri } \\
\text { perut, } \\
\text { Jaundice }\end{array}$ & Transeksi CHD & E-2 & $\begin{array}{l}\text { PTBD: } \\
\text { Pasang pigtail } \\
\text { Laparotomi: } \\
\text { HY Roux en Y }\end{array}$ & Baik \\
\hline 12 & Biloma & $\begin{array}{l}\text { Bile leak dari duktus } \\
\text { sistikus }\end{array}$ & $\mathrm{A}$ & $\begin{array}{l}\text { Laparotomi } \\
\text { drainase biloma }\end{array}$ & Baik \\
\hline 13 & $\begin{array}{l}\text { Nyeri } \\
\text { perut, } \\
\text { Jaundice }\end{array}$ & $\begin{array}{l}\text { CBD terklip, oklusi } \\
\text { total CBD }\end{array}$ & E-1 & $\begin{array}{l}\text { Laparoskopi } \\
\text { release klip } \\
\text { + pasang T-tube }\end{array}$ & Baik \\
\hline 14 & $\begin{array}{l}\text { Nyeri } \\
\text { perut, } \\
\text { Jaundice }\end{array}$ & Bile leak CHD & E-2 & $\begin{array}{l}\text { ERCP: } \\
\text { Spingterotomi } \\
\text { Gagal kanulasi } \\
\text { Laparotomi: } \\
\text { HY Roux en Y }\end{array}$ & Baik \\
\hline
\end{tabular}

*HY: Hepatiko Yeyenostomi Roux en Y 


\section{PEMBAHASAN}

Bile duct injury (BDI) banyak terjadi dalam praktek klinis. Mekanisme terjadinya cedera, upaya perbaikan sebelumnya, risiko bedah dan status kondisi umum penderita berpengaruh penting dalam pengambilan keputusan untuk menentukan tindakan diagnostik maupun terapetik. BDI dapat terjadi pada pembedahan kolesistektomi baik open maupun laparoskopik, bisa juga pada operasi pankreas dan gaster, dimana 80\%-85\% diantaranya ditemukan pada laparoskopi kolesistektomi. ${ }^{2}$ Walaupun secara statistik tidak signifikan, BDI pada laparoskopi kolesistektomi dilaporkan dua kali lebih sering ketimbang pada open kolesistektomi $(0,3 \%$ open vs $0,6 \%$ laparoskopi).

Dua hal yang paling sering di temuai pada BDI adalah bile leak atau obstruksi duktus bilier. Kejadian bile leak lebih mudah dikenali selama minggu pertama post operasi. Adanya cairan bile yang keluar melalui drain, luka operasi atau luka port laparoskopi. Pasien biasanya mengeluh nyeri abdomen yang difus, mual, demam dan bising usus yang lemah. Selain itu juga bisa berupa adanya kumpulan bile, lekositosis, peritonitis dan hiperbilirubinemia. ${ }^{2}$ Pada tipe yang obstruksi, yang paling sering ditemukan adalah adanya pola obstruksi pada test fungsi hati dan disertai jaundice. Sebagian besar pasien seperti ini memiliki cidera yang kompleks Strasberg tipe E yang diketahui selama periode transoperatif. Namun jika tidak diidentifikasi selama minggu pertama pasca operasi, pasien akan memiliki bahaya yang tersembunyi dengan timbulnya nyeri perut yang berulang, kolangitis maupun kumpulan bile. Beberapa stenosis parsial dan terisolasi hanya di duktus sector kanan (Strasberg B dan C) biasanya akan menampakkan gejala nyeri perut, pruritus, kelemahan umum, demam dan perubahan intermiten tes fungsi hati.

Keterlambatan diagnosis, beberapa upaya perbaikan, dan perawatan medis yang diabaikan akan menambah beratnya penyakit dan meningkatkan kompleksitas perbaikan duktus bilier. Terlambatnya penanganan BDI dapat menyebabkan penyakit kronis hati, sirosis dan hipertensi portal dimana transplantasi hati menjadi harapan terakhir penyembuhan. ${ }^{2}$

Pasien post kolesistektomi yang mengeluh jaundice, demam dan menggigil harus di cek alkali phosphatase karena merupakan tes yang paling sensitive untuk mendiagnosis adanya obstruksi jaundice. ${ }^{3}$ Kemudian harus dilakukan USG liver dan duktus biliaris bagian atas untuk mencari apakah terdapat dilatasi duktus biliaris atau adanya sisa batu sistem bilier. Cara terbaik untuk mendiagnosis striktur atau oklusi dari saluran bilier dan menentukan batas yang tepat adalah dengan MRCP atau PTC.Endoskopi Retrograde Colangio 
Pankreaticography (ERCP) aman namun kurang efektif dari pada MRCP dan sering hanya menunjukkan gambaran saluran bawah oklusi/ striktur.Faktor-faktor yang mungkin menyebabkan BDI selama kolesistektomi bisa berupa adanya fibrosis di segitiga Calot, kolesistitis akut, obesitas, pendarahan local, varian anatomi, dan lemak dalam porta hepatis. ${ }^{3}$

Sebagian besar $(57,14 \%)$ kasus BDI pada studi ini dilakukan rekonstruksi dengan hepatiko yeyenostomi Roux en Y karena banyak studi yang melaporkan bahwa BDI mempunyai hasil yang sangat baik yang direkonstruksi dengan sambungan tension free mukosa ke mukosa hepatiko yeyenostomi Roux en Y sehingga saat ini prosedur ini adalah yang paling sering dipakai untuk rekonstruksi BDI. ${ }^{4}$

\section{KESIMPULAN}

Bile duct injury (BDI) banyak terjadi dalam praktek klinis, dua hal yang paling sering di temuai pada BDI adalah bile leak atau obstruksi duktus bilier. Modalitas diagnostik untuk BDI dapat berupa USG, MRCP, ERCP atau PTBD.Sebagian besar kasus BDI dapat direkonstruksi dengan hepatiko yeyenostomi dengan hasil baik dan memuaskan. 


\section{REFERENSI}

1. Mehmet Karabulut etal, Diagnosis and Treatment of Iatrogenic BileDuct Injuries, Medical Journal of Bakırköy, Volume 8, Number 3, 2012

2. Muhammad Saddique et al, Bile duct injury: Management and outcome, Journal of surgery Pakistan (International) 17 (4) October-December 2012

3. Dhiraj Agarwal et al,Prospective Review Study of 84 Cases of Post-Cholecystectomy Bile Duct Injuries, IOSR Journal of Dental and Medical Sciences (IOSR-JDMS) $e$ Volume 14, Issue 8 Ver. VIII (Aug. 2015), PP 92-94.

4. Muhammad Saddique et al, Bile Duct Injury: Management andOutcome, Journal of Surgery Pakistan (International) 17 (4) October - December 2012.

5. Beata Jabłońska et al, Iatrogenic bile duct injuries: Etiology, diagnosis and Management, World J Gastroenterol September 7, 2009 Volume 15 No. 33.

6. Beata Jabłońska, Recontructive Biliary Surgery in the Treatment of Iatrogenic Bile Duct Injuries, Medical University of Silesia in Katowice, Department of Digestive Tract Surgery Poland,www.intechopen.com.

7. Miguel Angel Mercado, Classification and management of bile duct injuries, World $J$ Gastrointest Surg 2011 April 27; 3(4): 43-48.

8. Ajay K. Sahajpal et al, Bile Duct Injuries Associated WithLaparoscopic Cholecystectomy, Arch Surg/vol 145 (No. 8), Aug 2010.

9. M. Eikermann et al, Prevention and treatment of bile duct injuries during laparoscopiccholecystectomy: the clinical practice guidelines of the European Association for Endoscopic Surgery (EAES), Surg Endosc (2012) 26:3003-3039. 